\section{World at work: Charcoal producing industries in northeastern Brazil}

\section{Kato, D M DeMarini, A B Carvalho, M A V Rego, A V Andrade, A S V Bomfim, D Loomis}

\section{A poorly mechanised process, dependent on human labour}

7 e charcoal production process has been known since the Bronze Age, and was vital to metallurgy until the discovery of the conversion of coal to coke at the beginning of the 18th century. ${ }^{1}$ Brazil, now the largest charcoal producer of the world, with more than 12 million metric tons in year $2002,{ }^{2}$ has preserved its charcoal based industries in large part because it has extensive iron deposits and very few coal mines. ${ }^{3}$

\section{TASKS OF THE JOB}

In Brazil, charcoal is produced on an industrial scale primarily by carbonisation of wood in masonry kilns, in a poorly mechanised process that is highly dependent on human labour. ${ }^{14}$ We observed the charcoal producing process in the northeastern area of Bahia State, Brazil, and identified the following tasks.

\section{Logging}

Charcoal making begins with the falling of trees, usually Eucalyptus or Pinus grown in plantations. After lumberjacks have cut the tree using a chain saw, helpers take away the branches, and the timber is cut to size and allowed to air dry.

\section{Transportation of wood}

Wood transporters pile up logs in areas that tractors or trucks can access. Tractor and truck helpers load timber in the cutting areas and pile it at the kiln area. Helpers travel from the cutting area to the kiln area on the top of the log pile on the loaded vehicle. Workers stay on the top of the pile for the loading and unloading process (fig 1 ).

\section{Filling the kiln}

Up to hundreds of brick kilns are built in each site, in single or multiple lines so that they can be loaded and unloaded consecutively. The shape of the kilns varies from a hemisphere to a cylinder with round tops; the latter can be up to $2.5 \mathrm{~m}$ high, and may have metal beams to support the vertical walls as well as lateral exhaust systems. A kiln has an entrance used to load logs, and an exit, on the opposite side, to unload the finished charcoal.

To start filling a kiln, the charcoal exit is sealed with bricks and plastered with clay. The inner space is filled from the wall to the centre of the kiln, and from the charcoal exit to the log entrance. The density and the position of the wood inside the kiln are determinants of charcoal productivity. When the kiln is full, the entrance is sealed, and a worker climbs to the top of the kiln to start the fire.

\section{Pyrolysis}

The combustion process takes up to seven days. The duration of the combustion depends on the size of the kiln, and the density and freshness of the wood (fig 2). A worker known as a burner checks the colour and the amount of the smoke, which indicate the stage of combustion. The burner or a mud-worker gradually fills openings with clay while the pyrolysis progresses, in order to guarantee that the heat inside the kiln is appropriate for the production of

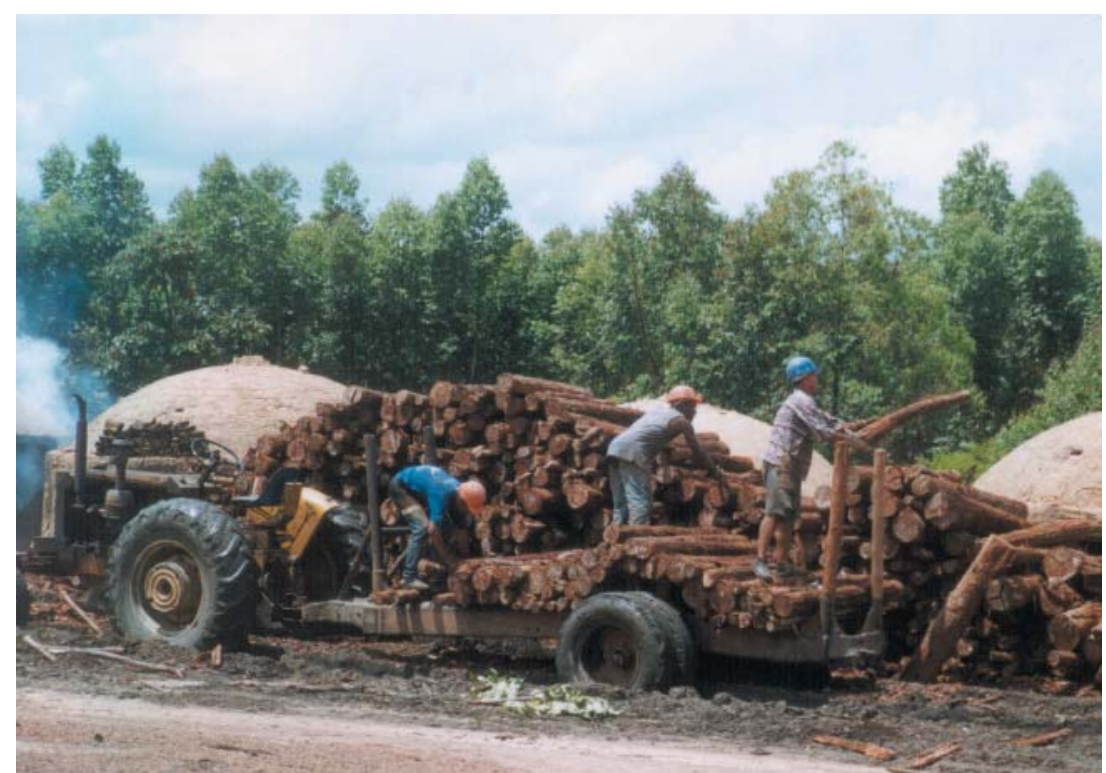

Figure 1 Unloading a tractor trailer in the kiln area. climb a ladder to empty the container charcoal (fig 3). A fire that is too intense can collapse the woodpile, demolishing the kiln. The burner's job requires less physical force than a kiln worker's, but he works round-the-clock, supervising several burning kilns. The burning task is usually performed by older workers, who were former kiln workers renowned for their knowledge and able to adapt to the peculiar work shift.

\section{Removal of charcoal}

When the pyrolysis is complete, kiln workers manually remove the charcoal using wheelbarrows, metal baskets, shovels, or pitchforks, and pile it nearby. While executing this task, workers are usually exposed to smoke and covered by charcoal dust (fig 4). The inner temperature of the kiln might still be high due to smouldering pieces while this work progresses, and sudden contact with oxygen during the opening of the kiln may restart a fire. Kiln workers work alone or in pairs, loading and unloading kilns alternately. When working alone in large cylindrical kilns, they execute one of the tasks in a day.

\section{Transportation of charcoal}

Charcoal is transported by trucks from the sites to foundries, where it is used in making pig-iron. Only a few charcoal sites are equipped with silos that allow direct truck loading. More frequently, charcoal-carriers fill up plastic drums or wicker baskets with charcoal, place them over their shoulders or head, and into a truck (fig 5).

The production sites we visited were scattered in the woods, with 5-50 workers at each site. These sites were usually 


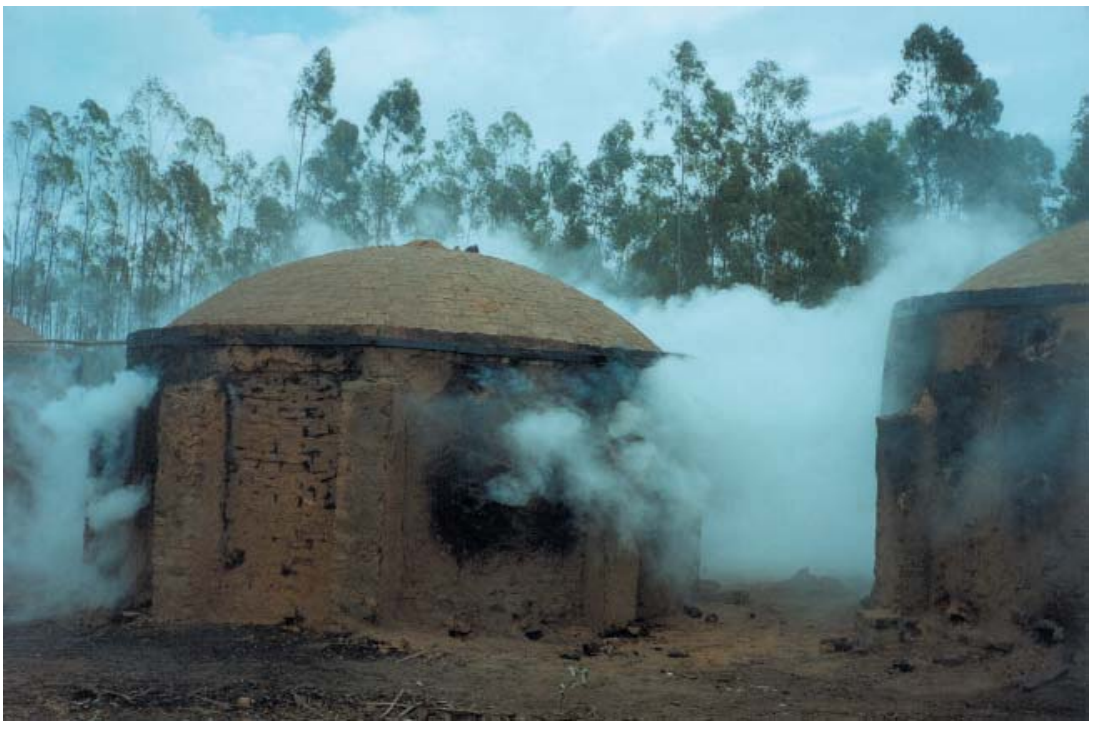

Figure 2 A kiln during a combustion process.

located far from towns, and access to them could be difficult because of poor road conditions, especially in the rainy season. Many workers shared common dormitories located inside the company perimeter, working uninterruptedly at the site for 12 days, and going home after receiving their wages once or twice a month. Logging area workers were sometimes transported by trucks or tractors to cutting areas far from the dormitories. Living conditions at most of the production sites were primitive. Running water and electricity were seldom available, and workers' food consumption was conditioned by the lack of refrigeration. Drinking water was sent in trucks, but the water used to extinguish fires and for cleaning was collected from nearby natural water sources.

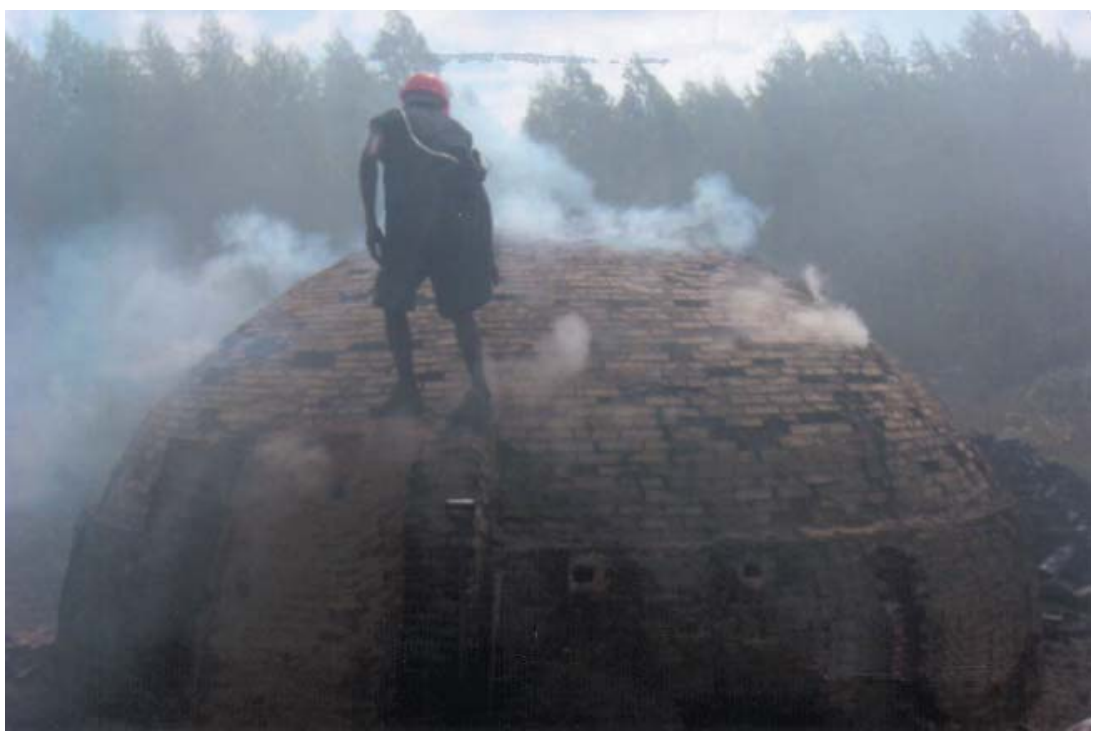

Figure 3 Climbing a kiln to check fire. Supervisors controlled the productivity of each worker, and it was measured specifically according to each executed activity. For example, kiln workers' charcoal production could be assessed by the number of times they carried a full wheelbarrow out of a kiln or by the number of kilns that were burnt in a week, and charcoal carriers were paid according to the number of loaded trucks.

\section{HAZARDS OF THE JOB AND IN THE WORKPLACE}

Table I summarises hazardous situations and potential health consequences reported by workers we interviewed. Charcoal carriers reported that the risk of injuries due to the weight and the lack of equilibrium while climbing the

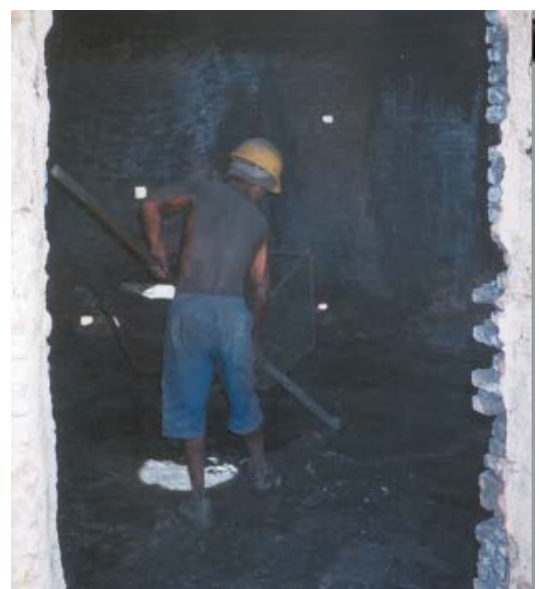

Figure 4 Taking charcoal out of a kiln.

ladder or the truck increased during rainy days, when the charcoal was soaked with water and the ladder was slippery.

Wood smoke generated in kilns is a complex mixture composed of liquid, solid, and gaseous particles. ${ }^{56}$ Many components are irritant and genotoxic, such as nitrogen and sulphur oxides, benzene, methanol, and styrene, phenols, naphthalene, aldehydes, organic acids, and polycyclic aromatic hydrocarbons. $^{78}$ Studies on health effects of exposure to wood smoke in environmental and occupational settings have shown increased prevalence of respiratory symptoms and diseases due to the effect of wood smoke on respiratory function. ${ }^{9-12}$ Because charcoal workers were hired by the companies to execute specific jobs all year long, kiln workers spent their working time in the kiln area. Although workers tried to work up wind from burning kilns to avoid wood smoke, exposure was frequently unavoidable. We assessed the wood smoke exposure among charcoal workers in northeastern Bahia using a naphthalene metabolite in urine. ${ }^{13}$ The geometric mean of urinary 2-naphthol among 100 kiln workers' urine samples was $7.17 \mathrm{mmol} / \mathrm{mol}$ of creatinine, and among 67 tree cutting workers' samples was $1.35 \mathrm{mmol} / \mathrm{mol}$ of creatinine. These levels are higher than those previously reported for other workers exposed occupationally. ${ }^{14} 15$

When protective equipment was available, most workers agreed to use it, although they complained about discomfort. Some charcoal carriers did not use helmets because they carried their load on their heads (fig 5).

Ellegard $^{16}$ observed that charcoal workers in Zambia reported more cough but less breathlessness, wheezing, and difficulties to inhale or exhale compared to urban housewives, and indicated that subjects susceptible to wood smoke 


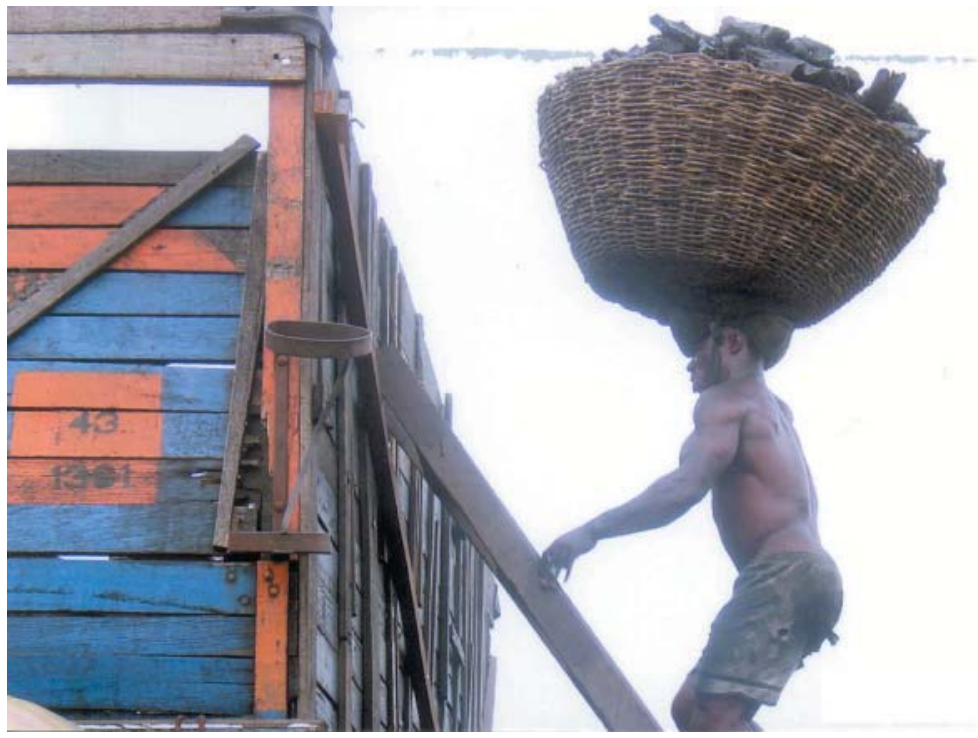

Figure 5 Loading a charcoal truck.

would tend to find some other occupation rather than making charcoal. Our observations also supported this hypothesis. Quoting some workers: "This is not a job for anybody. You have to stand the wood smoke or you just go away and look for another job."

Ellegard $^{16}$ reported backache, heat, and cough as the Zambian charcoal workers' main complaints. In a study from another part of Brazil by Dias and colleagues, ${ }^{4}$ as well as in our investigation, workers reported many sources of injuries and complained about lumbar pain and muscle soreness due to heavy loads and repetitive movements (fig 6). Excessive heat during work was credited mainly to the task of unloading the kiln, but during the summer, any of the jobs in charcoal production were subject to high humidity and high temperatures. The temperature of the working environment and the charcoal dust dispersed while unloading a kiln could also affect the workers' eyes.

\section{MEASURES TO PROTECT WORKERS}

Several of the concerns we have described regarding work conditions and workers' health deserve further investigation. However, these observations have been instrumental in promoting improvements in the charcoal plants to guarantee better health conditions for the workers. The proposed safety measures are:

- Build kilns in a single line, observing the prevailing wind direction, and locating the kilns in such way as to reduce smoke exposure

- Consider the height of the workers and the size of the logs in building kilns. Cylindrical kilns seemed to be easier to load and better adapted ergonomically

- Build kilns with lateral exhaust chimneys to reduce direct wood smoke exposure on burners and mud-workers

- Start the combustion process without climbing the kiln roof

Table 1 Reported potential hazardous conditions and health risks by charcoal workers in northeastern Bahia, 2001-02

\begin{tabular}{|c|c|c|}
\hline Activity & Hazardous situation & Health consequences \\
\hline $\begin{array}{l}\text { Starting fire } \\
\text { Burning } \\
\text { Unloading kilns }\end{array}$ & $\begin{array}{l}\text { Wood pile, wood pieces } \\
\text { Wood pile collapse } \\
\text { Repetitive movements, weight of the wood } \\
\text { Hidden insects, scorpions, and snakes } \\
\text { Climbing a kiln } \\
\text { Wood smoke and charcoal particulate } \\
\text { Fall of the kiln roof or wall } \\
\text { Kiln heat or fire while unloading } \\
\text { Kiln heat and rain } \\
\text { Confined space }\end{array}$ & $\begin{array}{l}\text { Fall, slip, and trip from the pile } \\
\text { Cut, crush, or laceration of hand, foot, or limbs; being struck by logs } \\
\text { Back and muscle pain, fatigue, spinal hernia } \\
\text { Poisonous bites } \\
\text { Fall and slip from the rooftop or ladder } \\
\text { Eye and throat irritation, sinusitis, tuberculosis, lung diseases } \\
\text { Injuries } \\
\text { Burns, eye irritation } \\
\text { Cold/flu } \\
\text { Dizziness, fainting }\end{array}$ \\
\hline $\begin{array}{l}\text { Tractor/truck driv } \\
\text { Loading and } \\
\text { unloading trucks }\end{array}$ & $\begin{array}{l}\text { ctor/truck loaders } \\
\text { Wood pile collapse } \\
\text { Repetitive movements, log weight } \\
\text { Hidden insects, scorpions, and snakes } \\
\text { Road conditions, traffic } \\
\text { Inadequate vehicle maintenance } \\
\text { Truck/tractor fuel and engine exhaust }\end{array}$ & $\begin{array}{l}\text { Fall, slip, and trip from the pile } \\
\text { Cut, crush, or laceration of hand foot or limbs; being struck by logs } \\
\text { Back and muscle pain, hernia } \\
\text { Poisonous bites } \\
\text { Vehicle fall, wood pile collapse, injuries, traffic accidents } \\
\text { Skin and respiratory tract irritation }\end{array}$ \\
\hline $\begin{array}{l}\text { Loggers and log } \\
\text { Logging }\end{array}$ & $\begin{array}{l}\text { Chainsaw weight } \\
\text { Chainsaw malfunction } \\
\text { Chainsaw engine (gasoline) fume } \\
\text { Tree fall while cutting }\end{array}$ & $\begin{array}{l}\text { Muscle pain } \\
\text { Severe cuts } \\
\text { Respiratory tract irritation } \\
\text { Injuries }\end{array}$ \\
\hline $\begin{array}{l}\text { Kiln burners } \\
\text { Burning kiln } \\
\text { inspection }\end{array}$ & Wood smoke & $\begin{array}{l}\text { Eye and respiratory tract irritation } \\
\text { Lung disease }\end{array}$ \\
\hline $\begin{array}{l}\text { Charcoal carriers } \\
\text { Loading charcoal }\end{array}$ & $\begin{array}{l}\text { Climbing up stairs } \\
\text { Charcoal dust }\end{array}$ & $\begin{array}{l}\text { Slips and falls } \\
\text { Eye irritation }\end{array}$ \\
\hline
\end{tabular}




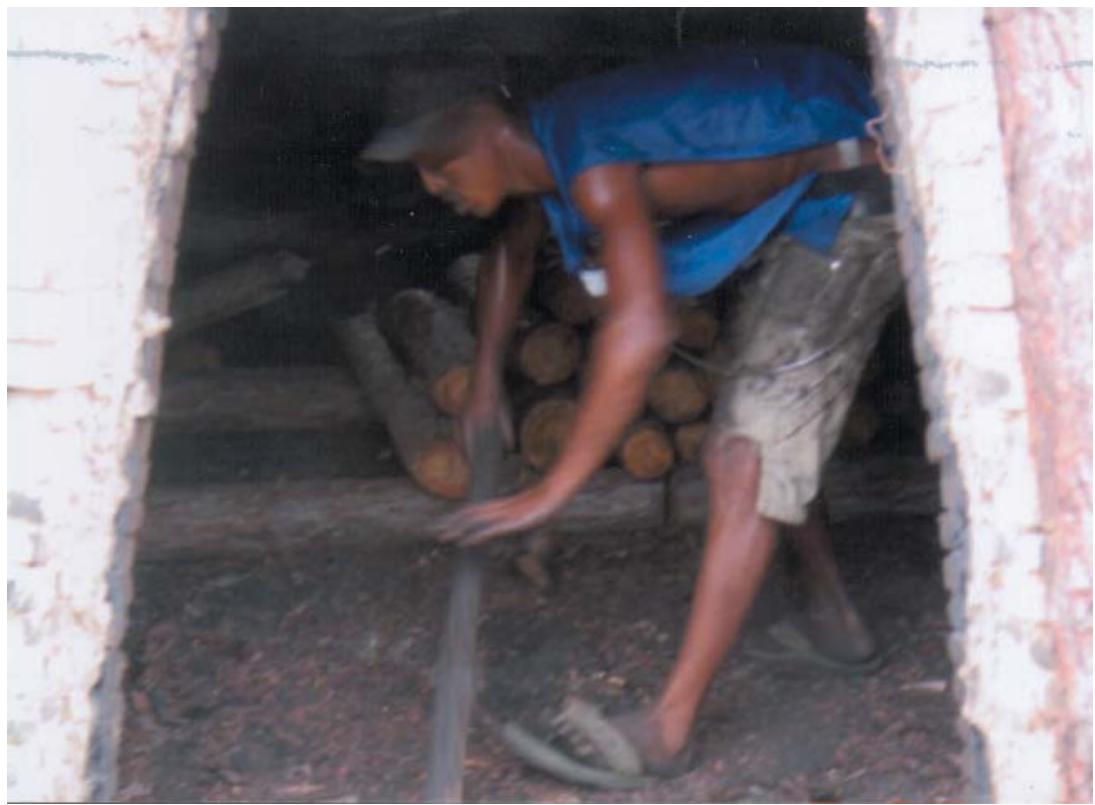

Figure 6 Filling the kiln.

- Work in pairs when unloading the kiln, to reduce the risks of being unattended in case of an injury

- Open both openings while unloading the kiln to increase air flow

- Mechanise both the loading and unloading of logs and the charcoal loading process

- Instruct workers on safety issues regarding machinery and equipment

- Do not allow workers to travel on the top of loaded vehicles

- Develop first-aid and emergency procedures. Install a communication system to be used in emergency situations

- Provide proper illumination for working sites and living areas.

Recently, due to efforts of inspectors of the Ministry of Labor and Employment, improvements have been introunloading by a mechanised process (fig 7). Starting a combustion process without climbing the kiln roof is another safety measure we recommended, but workers complained that their productivity was reduced when fire is set from the entrance opening.
However, the kiln worker's job cannot be replaced without a major change in the type and size of the kiln, and alterations in the kilns needs careful study of safety and productivity. Zucchi ${ }^{17}$ reported that larger rectangular kilns used in a charcoal company in Minas Gerais State presented higher risk of explosion and fires than traditional cylindrical ones. One of the companies we visited has begun investigating alternative kiln shapes to increase productivity in safer working conditions (fig 8).

There are many other charcoal producing sites in Brazil as well as in other parts of the world, where working and living conditions can be worse than described in this article. Among small producers, smaller masonry kilns or wood pile in a pit and covered with soil may be used to produce charcoal. In these operations, the same workers might execute all of the tasks of charcoal production, with exposure to all of the accompanying hazards. Although we found only male workers in the companies we visited, entire families, including children can be found involved with the activity in other areas. Although charcoal companies in northeastern Bahia use wood from cultivated trees, a third of the national charcoal production is still based on exploitation of natural resources, depleting forests. ${ }^{13-5}$ Therefore, there are also important social and environmental issues linked to charcoal production that should be taken into consideration in addition to workers' health and safety. ${ }^{1}$

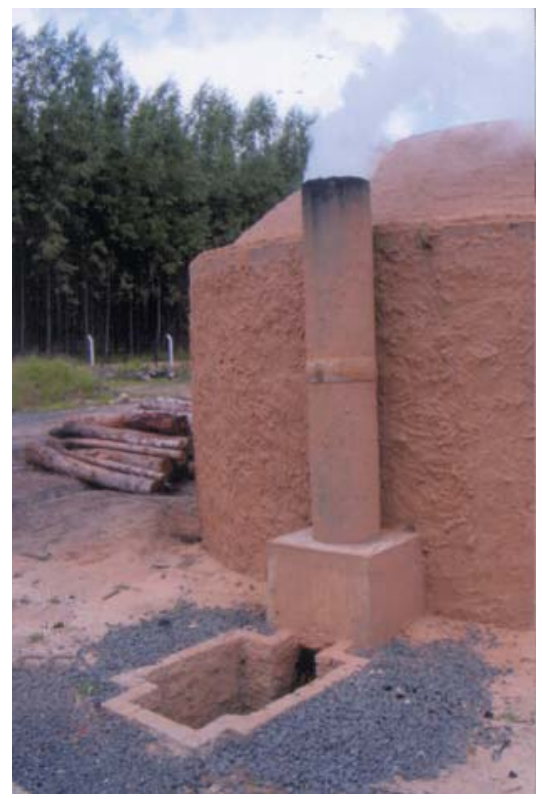

Figure 8 A kiln that enables starting fire from the bottom.

Figure 7 Silos that enable direct charcoal truck loading

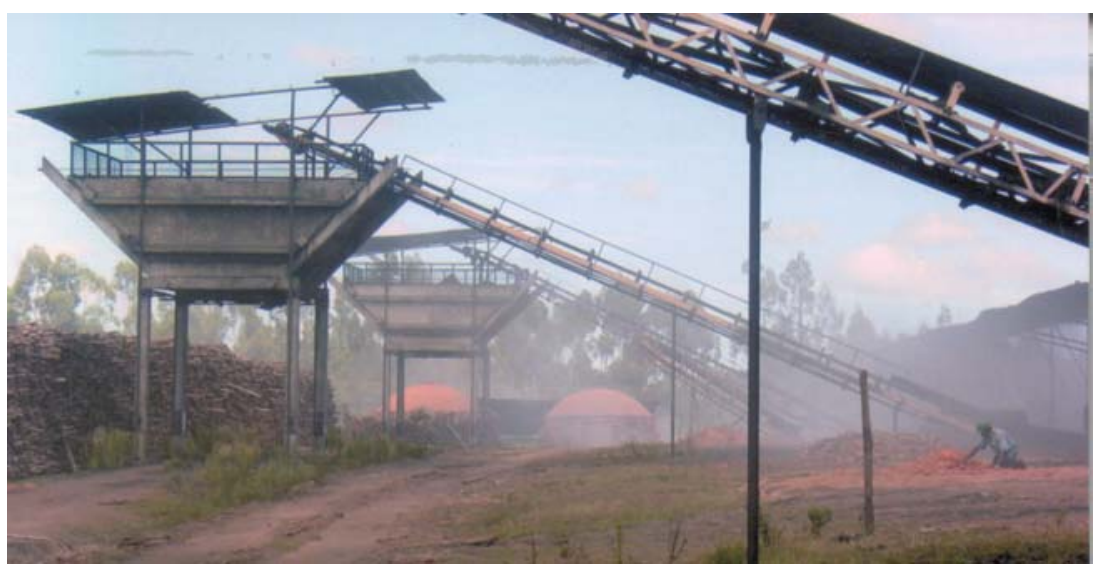




\section{ACKNOWLEDGEMENTS}

The authors thank Dr Vilma Santana, Drs Robert Millikan and Leena Nylander-French, Drs R Julian Preston, Russ Owen, Larry Claxton, and Dr Daniel Shaughnessy for their helpful comments on the manuscript. We greatly appreciate the participation of Lúcia Maria Rocha Nunes, Maryangela Santos, and other collaborators in Fundacentro and CESAT in the field research. We also thank the charcoal companies and all workers that agreed to participate in the study. This study was supported by FUNDACENTRO, USEPA, CESAT, and Bahia-Carolina Fellowship through a grant from the US National Institutes of Health/Fogarty International Center to the University of North Carolina at Chapel Hill (Grant No. 1 D43 TWO0082701). This manuscript has been reviewed by the National Health and Environmental Effects Research Laboratory, US Environmental Protection Agency, and approved for publication

Occup Environ Med 2005;62:128-132. doi: 10.1136/oem.2004.015172

\section{Authors' affiliations}

M Kato, A B Carvalho, A V Andrade,

A S V Bonfim, Fundacentro-CRBA, Salvador, 41820-770, Brazil

M A V Rego, Department of Preventive Medicine, Federal University of Bahia,

Salvador, $41100-100$, Brazi

D M DeMarini, Environmental Carcinogenesis Division, US Environmental Protection Agency, Research Triangle Park, NC 27711, USA

D Loomis, Departments of Epidemiology and Environmental Sciences and Engineering, School of Public Health, University of North Carolina, CB-7435, Chapel Hill, NC 27599 7435, USA
Correspondence to: $\operatorname{Dr} M$ Kato, FundacentroCRBA, r. Alceu Amoroso Lima, 142, Pituba, Salvador/Bahia, 41820-770, Brazil; mika@fundacentro-ba.gov.br

Ethics approval: This study received the approval of the Institutional Review Board of the University of North Carolina, School of Public Health, the Bioethics Committee of the Centro Estadual de Oncologia in Brasil, and the Human Subjects Research Review Official of the US Environmental Protection Agency.

\section{REFERENCES}

1 Medeiros JX. Charcoal-fueled steel production in Brazil: an exercise in environmental valuation. In: May PH, eds. Natural resource valuation and policy in Brazil. Methods and cases in conservation science. New York: Columbia University Press, 1999.

2 Food and Agriculture Organization of the United Nations (FAO). FAOSTAT-Forestry Data. http://apps.fao.org/faostat/form?collection = Forestry . Primary\&Domain $=$ Forestry\&servlet $=$ 1 \& hasbulk $=0$ \&version $=$ ext\&language $=E N$ (accessed April 2004)

3 Rosillo-Calle F, Rezende MA, Furtado P, et al. The charcoal dilemma. Finding sustainable solutions for Brazilian industry. London: Intermediate Technology Publications, 1996.

4 Dias EC, Assunção AA, Guerra CB, et al. Processo de trabalho e saúde dos trabalhadores na produção artesanal do carvão em Minas Gerais, Brazil [Labor process and workers' health in charcoal production in Minas Gerais, Brazil]. Cadernos de Saúde Pública 2002;18:267-77.

5 Smith K, Pennise D, Khummongkol $\mathrm{P}$, et al. Greenhouse gases forms small-scale combustion devices in developing countries: charcoal-making kilns in Thailand. EPA-600/R-99-109. United States Environmental Protection Agency Research and Development, December 1999.

6 Ré-Poppi N, Santiago-Silva MR. Identification of polycyclic aromatic hydrocarbons and methoxylated phenols in wood smoke emitted during production of charcoal. Chromatographia 2002;55:475-81.
7 Larson TV, Koenig JQ. Wood smoke: emissions and non-cancer respiratory effects. Annu Rev Public Health 1994;15:133-56.

8 International Agency of Research on Cancer (IARC). List of agents, mixtures or exposures classified as to their carcinogenic risk to humans up to date. http://monographs.iarc.fr/ monoeval/crthall.html (accessed April 2004)

9 Betchley C, Koenig JQ, van Belle G, et al. Pulmonary function and respiratory symptoms in forest firefighters. Am J Ind Med 1997;31:503-9.

10 Pintos J, Franco EL, Kowalski LP, et al. Use of wood stoves and risk of cancers of the upper aero-digestive tract: a case-control study. Int J Epidemiol 1998;27:936-40.

11 Bruce N, Perez-Padilla R, Albalak R. Indoor air pollution in developing countries: a major environmental and public health challenge. Bull World Health Organ 2000;78:1078-92

12 Tzanakis N, Kallergis K, Bouros DE, et al. Shortterm effects of wood smoke exposure on the respiratory system among charcoal production workers. Chest 2001;119:1260-5

13 Kato $M$, Loomis D, Brooks $L M$, et al. Urinary biomarkers in charcoal workers exposed to wood smoke in Bahia State, Brazil. Cancer Epidemiol Biomarkers Prev 2004; 13:1005-12.

14 Lee CY, Lee JY, Kang JW, et al. Effects of genetic polymorphisms of CYP1A1, CYP2E1, GSTM1, and GSTT1 on the urinary levels of 1hydroxypyrene and 2-naphthol in aircraft maintenance workers. Toxicol Lett 2001;123:115-24.

$15 \mathrm{Kim} \mathrm{H}$, Cho $\mathrm{SH}$, Kang JW et al. Urinary $1-$ hydroxypyrene and 2-naphtol concentrations in male Koreans. Int Arch Occup Environ Health 2001;74:59-62

16 Ellegard A. Health effect of charcoal production from earth kilns in Chisamba Area, Zambia. Working paper. Energy environment and development series 34. Stockholm: Stockholm Environment Institute, 1994.

17 Zucchi PS. Das carvoarias às plantas de carbonização: o que mudou na segurança e saúde dos trabalhadores? In: Salim CAM, Carvalho LF, eds. Saúde e segurança no ambiente de trabalho: contextos e vertentes. Belo Horizonte: Segrac, 2002. 